\title{
Renal toxicity and arterial hypertension in rats chronically exposed to vanadate
}

Paolo Boscolo, Marco Carmignani, Anna Rita Volpe, Mario Felaco, Goffredo Del Rosso, Giovanni Porcelli, Giovanni Giuliano

\begin{abstract}
The effects of 1,10 , or $40 \mu \mathrm{g} / \mathrm{ml}$ of vanadium, given for six or seven months as sodium metavanadate in drinking water on cardiovascular and biochemical variables and the electrolyte metabolism of male Sprague-Dawley rats were investigated. At the end of the exposure period, all animals exposed to vanadate had increased systolic and diastolic blood pressure. This effect was not dose dependent and heart rate and cardiac inotropism were not affected. The role of defective renal function and electrolyte metabolism in such effects was supported, in the rats exposed to 10 and 40 ppm of vanadium, by the following changes: $(a)$ decreased $\mathrm{Na}^{+}{ }^{+} \mathrm{K}^{+}$-ATPase activity in the distal tubules of nephrons; (b) increased urinary excretion of potassium; (c) increase in plasma renin activity and urinary kallikrein, kininase $I$, and kininase II activities; (d) increased plasma aldosterone (only in the rats treated with $10 \mathrm{ppm}$ of vanadium). The alterations in the rats exposed to $1 \mathrm{ppm}$ of vanadium were: $(a)$ reduced urinary calcium excretion; (b) reduced urinary kallikrein activity; (c) reduced plasma aldosterone. These results suggest that blood hypertension in rats exposed to vanadate depends on specific mechanisms of renal toxicity related to the levels of exposure.
\end{abstract}

(Occup Environ Med 1994;51:500-503)

There is no certainty about the dietary requirement of humans for vanadium as in no animal has it been proved that vanadium deficiency consistently impairs biological function. ${ }^{1}$ Nutritional studies, however, indicate that vanadium is a very active biological substance that interacts with other components of the diet. ${ }^{12}$ According to in vitro and in vivo studies, vanadate $\left(\mathrm{VO}_{3}^{-},+5\right.$ oxidation state) enters cells where it is reduced almost completely to the vanadyl form $\left(\mathrm{VO}^{2+}\right.$, +4 oxidation state). ${ }^{13}$ Sabbioni et al suggested that intracellular excess of vanadate, which may not be reduced to the vanadyl state, would be responsible for toxic effects in cell cultures. ${ }^{3}$ Both vanadate and vanadyl forms are able to specifically affect the activity of several enzymes; for example, adenylate cyclase activity is stimulated by vanadate, whereas $\mathrm{Na}^{+}, \mathrm{K}^{+}$-ATPase, phosphotransferases, phosphohydrolases, and peroxi- dases are inhibited.

The concentrations of vanadium in the environment are increasing. Combustion of coal and oil in power plants for electric production mobilised about 10000-20000 tonnes of vanadium/year in the past decade. ${ }^{5}$ Environmental vanadium may affect the health of humans through digestion of contaminated food or retention of inhaled vanadium compounds. The inhalation of vanadium induced respiratory disorders in workers cleaning oil fired boilers or handling petroleum. ${ }^{6}$

Within the cardiovascular system, exposure to vanadate induced the increase of both blood pressure and heart rate in SpragueDawley rats. ${ }^{7-9}$ In these animals, baroafferent sensitivity and vagal parasympathetic activity were reduced, whereas sympathetic tone and cardiovascular responsiveness of $a_{2}, \beta_{1}$, and $\beta_{2}$ adrenergic receptors were augmented; the hypotensive and positive inotropic effects of bradykinin were also potentiated, indicating that vanadium affects the kallikrein-kinin system. ${ }^{89}$

In another study, sodium metavanadate, given by intravenous infusion to conscious dogs, increased systemic blood pressure, total peripheral resistance, pulmonary arterial pressure, and cardiac output, and suppressed plasma renin activity. ${ }^{10}$

The purpose of our study was to investigate whether, in Sprague-Dawley rats, chronic exposure to doses of vanadium below those used previously, ${ }^{7-9}$ could modify cardiovascular homeostasis through effects on the kallikrein-kinin and renin-angiotensin systems.

\section{Material and methods}

FIRST EXPERIMENT

Eighteen male weaning Sprague-Dawley rats, randomly divided into three equal groups, were housed in stainless steel cages and kept on a standard laboratory diet. One group received $40 \mu \mathrm{g} / \mathrm{ml}$ of vanadium, and the second group $10 \mu \mathrm{g} / \mathrm{ml}$ of vanadium, as sodium metavanadate $\left(\mathrm{NaVO}_{3}\right)$, in drinking water for 210 days. The third group served as a control.

\section{SECOND EXPERIMENT}

Twelve male weaning Sprague-Dawley rats were randomly divided into two equal groups, housed in stainless steel cages, and kept on a standard laboratory diet. One group received $1 \mu \mathrm{g} / \mathrm{ml}$ of vanadium, as $\mathrm{NaVO}_{3}$, in drinking water for 180 days, whereas the other group served as a control. 
Table 1 Mean (SEM) blood pressure, heart rate, and maximum rate of rise of left ventricular isovolumetric pressure $(d P / d t)$ in rats chronically exposed to different doses of vanadium $(n=6)$

\begin{tabular}{|c|c|c|c|c|}
\hline \multirow{2}{*}{$\begin{array}{l}\text { Exposure to } \\
\text { vanadium }\end{array}$} & \multicolumn{2}{|c|}{ Blood pressure $(\mathrm{mm} \mathrm{Hg})$} & \multirow{2}{*}{$\begin{array}{l}\text { Heart rate } \\
\text { (beats/min) }\end{array}$} & \multirow{2}{*}{$\begin{array}{l}d P / d t \\
(m m H g / s)\end{array}$} \\
\hline & Systolic & Diastolic & & \\
\hline $\begin{array}{c}\text { First experim } \\
\text { Control } \\
10 \mathrm{ppm} \\
40 \mathrm{ppm}\end{array}$ & $\begin{array}{l}106(7) \\
137(5)^{\star} \\
132(4)^{\star}\end{array}$ & $\begin{array}{c}85(5) \\
112(5)^{\star} \\
114(7)^{\star}\end{array}$ & $\begin{array}{l}356(12) \\
341(18) \\
365(21)\end{array}$ & $\begin{array}{l}4208(364) \\
4601(239) \\
4648(323)\end{array}$ \\
\hline $\begin{array}{l}\text { Second exper } \\
\text { Control } \\
1 \mathrm{ppm}\end{array}$ & $\begin{array}{l}108(5) \\
130(4)^{\star}\end{array}$ & $\begin{array}{c}84(4) \\
106(3)^{\star}\end{array}$ & $\begin{array}{l}353(8) \\
348(9)\end{array}$ & $\begin{array}{l}4550(624) \\
4732(521)\end{array}$ \\
\hline
\end{tabular}

${ }^{\star} \mathrm{p}<0.05 v$ control. preload and afterload according to Crawford et $a l,{ }^{11}$ and Davidson et al. ${ }^{12}$ Heart rate was measured by a Beckman cardiotachometer coupler, that was triggered by the $R$ peak of the lead II electrocardiogram. The cardiovascular variables were continuously monitored on a Beckman type RM dynograph recorder (Beckman Instruments, Sciller Park, IL, USA) after stabilisation for 30 minutes.

After cardiovascular measurements, blood samples were collected from the carotid artery for the determination of plasma renin activity $^{13}$ and plasma aldosterone. ${ }^{14}$

Samples of several tissues were then excised for histopathological examination by light microscopy. The $\mathrm{Na}^{+}, \mathrm{K}^{+}$-ATPase activity was assayed by a histochemical method ${ }^{15}$ in the kidneys of rats exposed to $40 \mathrm{ppm}$ of vanadium. Samples of tissues were also excised for the determination of vanadium by neutron activation analysis. ${ }^{89}$ (This part of the study has not yet been completed.)

Kallikrein activity, ${ }^{16}$ kininase I and II activities, ${ }^{17}$ and creatinine, total nitrogen, proteins, sodium, potassium, and calcium were measured in the 24 urine samples by standard techniques.

The statistical analysis of the data was made by the Dunnet $t$ test for multiple comparison ${ }^{18}$ and was considered to be significant when $\mathrm{p}$ values were $<0.05$. A French catheter tip pressure ducer (Millar instruments, Houston, TX, USA) inserted in the right common carotid artery and advanced to the left ventricle, was used to determine left isovolumetric pressure (dP/dt). A biotronex BL 620 derivative computer (Biotronex Laboratories, Kensington, MA, USA) was attached to the system and was adjusted to minimise the expression of

\section{Results}

Systolic and diastolic blood pressure, but not cardiac inotropism ( $\mathrm{dP} / \mathrm{dt}$ ) and heart rate, were augmented in all the rats exposed to vanadium. These changes were not dosedependent (table 1).
(A) $\mathrm{Na}^{+}, \mathrm{K}^{+}-A T$ Pase in control rats and $(B)$ in rats exposed to $40 \mathrm{ppm}$ of vanadium. The distal tubules of controls contain more ATPase activity than the proximal tubules. Activity of ATPase is reduced in rats exposed to vanadate mainly in the distal tubular cells. Originally $\times 400$.

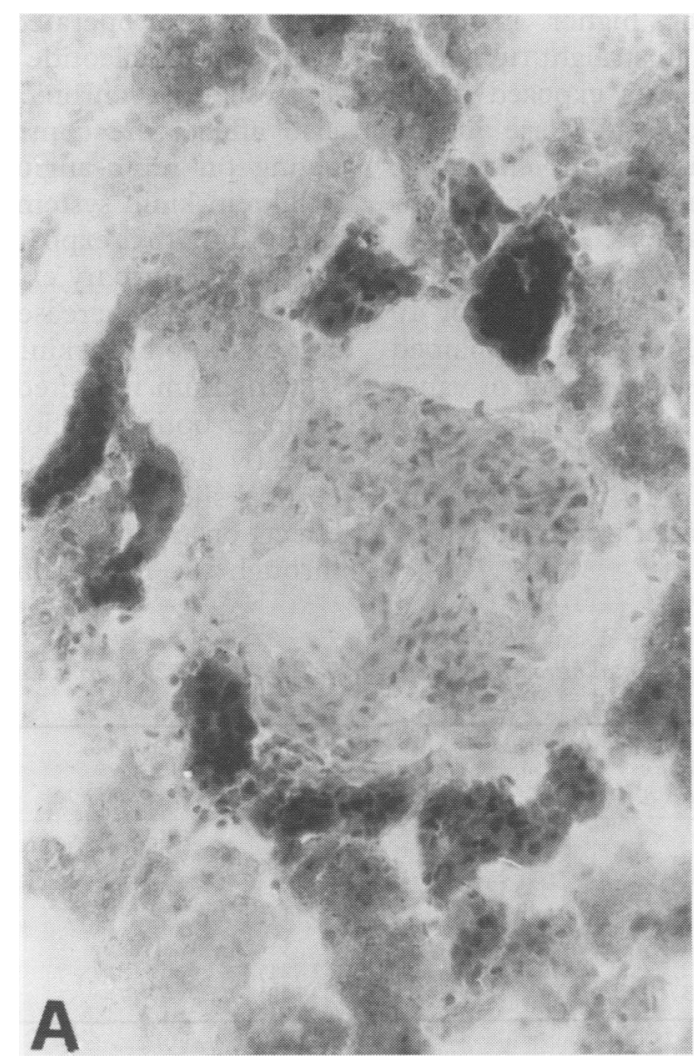


Table 2 Mean (SEM) plasma renin activity (PRA) and plasma aldosterone in rats chronically exposed to different doses of vanadium $(n=6)$

\begin{tabular}{lll}
\hline $\begin{array}{l}\text { Exposure to } \\
\text { vanadium }\end{array}$ & $\begin{array}{l}\text { PRA } \\
(\mathrm{ng} / \mathrm{ml} / \mathrm{h})\end{array}$ & $\begin{array}{l}\text { Plasma aldosterone } \\
(\mathrm{pg} / \mathrm{ml})\end{array}$ \\
\hline $\begin{array}{l}\text { First experiment: } \\
\quad \text { Control }\end{array}$ & $10 \cdot 3(2 \cdot 7)$ & $188(57)$ \\
$10 \mathrm{ppm}$ & $47 \cdot 5(14 \cdot 9)^{\star}$ & $554(160)^{\star}$ \\
$40 \mathrm{ppm}$ & $40 \cdot 6(12 \cdot 4)^{\star}$ & $265(61)$ \\
Second experiment: & & \\
$\quad$ Control & $13.4(3 \cdot 4)$ & $264(22)$ \\
$1 \mathrm{ppm}$ & $10 \cdot 6(2 \cdot 4)$ & $158(11)^{\star}$ \\
\hline
\end{tabular}

${ }^{\star} \mathrm{p}<0.05 v$ control

Table 3 Mean (SEM) activities of kallikrein and kininase I and II in $24 \mathrm{~h}$ urine samples from rats chronically exposed to different doses of vanadium $(n=6)$

\begin{tabular}{|c|c|c|c|}
\hline Exposure to vanadium & $\begin{array}{l}\text { Kallikrein } \\
\text { (nM/mg creat) }\end{array}$ & $\begin{array}{l}\text { Kininase I } \\
\text { (nM } \times 10^{-3} \text { of } \\
\text { hydrolysed substrate/mg } \\
\text { creatinine) }\end{array}$ & $\begin{array}{l}\text { Kininase II } \\
\text { (nM } \times 10^{-3} \text { of } \\
\text { hydrolysed substrate/mg } \\
\text { creatinine }\end{array}$ \\
\hline $\begin{array}{l}\text { First experiment: } \\
\text { Control } \\
10 \mathrm{ppm} \\
40 \mathrm{ppm}\end{array}$ & $\begin{array}{c}8.43(0.96) \\
13.67(2.54)^{\star} \\
11.72(0.80)^{\star}\end{array}$ & $\begin{array}{l}32.0(4 \cdot 2) \\
129.9(14.9)^{\star} \\
156 \cdot 8(9 \cdot 1)^{\star}\end{array}$ & $\begin{array}{l}1.83(0.26) \\
2.63(0.13)^{\star} \\
3.92(4.08)^{\star}\end{array}$ \\
\hline $\begin{array}{l}\text { Second experiment: } \\
\text { Control } \\
1 \mathrm{ppm}\end{array}$ & $\begin{array}{l}8.02(1.90) \\
4.36(0.60)^{\star}\end{array}$ & $\begin{array}{l}27 \cdot 6(5 \cdot 4) \\
56 \cdot 8(25 \cdot 3)\end{array}$ & $\begin{array}{l}2.23(0.33) \\
2.30(0.31)\end{array}$ \\
\hline
\end{tabular}

${ }^{\star} \mathrm{p}<0.05 v$ control.
Urinary kininase I and II activities were increased in the rats exposed to 40 and 10 ppm of vanadium and unchanged in those exposed to $1 \mathrm{ppm}$ of vanadium (table 3 ).

Vanadate treatment did not modify the urinary excretion of creatinine, total nitrogen, protein, and sodium. Urinary potassium decreased with dose, whereas calcium was reduced in the lowest exposure group (table 4).

\section{Discussion}

The results of this study show that chronic exposure of rats to different doses of vanadate, lower than those given in previous experiments, ${ }^{7-9}$ is able to induce arterial hypertension by increasing total peripheral resistance, as indicated by the lack of changes in cardiac inotropism and heart rate. Increased heart rate was found only in rats treated with $100 \mathrm{ppm}$ of vanadium where the central and peripheral sympathetic hyperactivity was counteracted by the reduction of both baroreflex activity and vagal tone. ${ }^{89}$

Male Sprague-Dawley rats exposed to vanadate according to the protocol of this investigation showed (after intravenous injection of substances and physiological agonists) increased cardiovascular responses to the specific stimulation of adrenergic receptors. ${ }^{19} 20$ These rats also showed increased responses to bradykinin (injected intravenously), dependent on activation of both bradykinin (vascu- $_{1}$

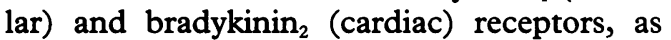
well as reduced baroafferent nerve activity and augmented plasma concentrations of catecholamines. ${ }^{20}$

The contractile processes in cardiac and vascular myocells are dependent, with some differences, on the availability of free calcium and are mainly regulated by the activity of both receptor operated slow calcium channels and cyclic nucleotide pathways. ${ }^{21}$ This study suggests that chronic exposure to vanadate also affects the contractility of myocells by acting on renin-angiotensin-aldosterone and kallikrein-kinin systems. This is confirmed by the finding that exposure to vanadate not only acts on the urinary excretion of kallikrein and kinins but increases the cardiovascular responses to bradykinin. ${ }^{891920}$

Vanadium inhibited synthesis or release of renin in both conscious dogs receiving vanadate by an intravenous route ${ }^{10}$ and in renal cortical slices incubated with vanadate. ${ }^{22}$ This effect on renin was only partly mediated through the inhibition of $\mathrm{Na}^{+}, \mathrm{K}^{+}$-ATPase,

Table 4 Mean (SEM) creatinine, total nitrogen, proteins, and electrolytes in 24 hrine samples from rats chronically exposed to different doses of vanadium $(n=6)$

\begin{tabular}{|c|c|c|c|c|c|c|}
\hline Exposure to vanadium & $\begin{array}{l}\text { Creatinine } \\
(m g / 24 h)\end{array}$ & $\begin{array}{l}\text { Total } \\
\text { nitrogen } \\
\text { (g/g creatinine) }\end{array}$ & $\begin{array}{l}\text { Proteins } \\
\text { (mg/g } \\
\text { creatinine) }\end{array}$ & $\begin{array}{l}\text { Sodium } \\
\text { (mEq/g } \\
\text { creatinine) }\end{array}$ & $\begin{array}{l}\text { Potassium } \\
\text { (mEq/g } \\
\text { creatinine) }\end{array}$ & $\begin{array}{l}\text { Calcium } \\
\text { (mg/g } \\
\text { creatinine) }\end{array}$ \\
\hline $\begin{array}{l}\text { First experiment: } \\
\text { Control } \\
10 \mathrm{ppm} \\
40 \mathrm{ppm}\end{array}$ & $\begin{array}{l}13(3) \\
16(2) \\
13(1)\end{array}$ & $\begin{array}{l}36(2) \\
33(2) \\
43(4)\end{array}$ & $\begin{array}{l}297(103) \\
269(71) \\
300(17)\end{array}$ & $\begin{array}{l}60(16) \\
69(9) \\
61(15)\end{array}$ & $\begin{array}{l}118(14) \\
169(18)^{\star} \\
221(28)^{\star}\end{array}$ & $\begin{array}{l}138(31) \\
130(22) \\
101(19)\end{array}$ \\
\hline $\begin{array}{l}\text { Second experiment: } \\
\text { Control } \\
1 \mathrm{ppm}\end{array}$ & $\begin{array}{l}15(2) \\
13(3)\end{array}$ & $\begin{array}{l}37(2) \\
32(1)\end{array}$ & $\begin{array}{l}231(21) \\
203(12)\end{array}$ & $\begin{array}{l}69(8) \\
67(7)\end{array}$ & $\begin{array}{l}113(25) \\
106(6)\end{array}$ & $\begin{array}{l}85(7) \\
55(5)^{\star}\end{array}$ \\
\hline
\end{tabular}


as in the presence of methoxyverapamil (a blocker of the slow calcium channels at the outer site) the effect of vanadate differed from that of ouabain (a specific $\mathrm{Na}^{+}, \mathrm{K}^{+}$-ATPase inhibitor) or of potassium free fluid. By contrast with the inhibition of renin release in vitro $^{22}$ and in dogs. ${ }^{10}$ chronic exposure to 10 or $40 \mathrm{ppm}$ of vanadium augmented the release of renin in rats. Slight morphological alterations and inhibition of $\mathrm{Na}^{+}, \mathrm{K}^{+}-$ ATPase in the cells of the macula densa and of the distal tubule may be responsible for this unexpected effect. At the same exposure, only the urinary excretion of potassium was increased, whereas in the rats treated with 100 $\mathrm{ppm}$ of vanadium the excretion of both potassium and sodium was augmented, 89 and in those given $1 \mathrm{ppm}$ of vanadium urinary calcium was reduced. Therefore, it seems that vanadate affects the efflux of electrolytes from tubular cells depending on the dose of exposure.

In the rats exposed to 10 or $40 \mathrm{ppm}$ of vanadium there was an increase of plasma renin activity and kininase I, kininase II, and kallikrein activities as well as of potassium excretion. This raises the possibility that there is a threshold effect for these alterations in the range of exposure from 2 to $10 \mathrm{ppm}$ of vanadium. Moreover, in the animals treated with 1,10 , or $40 \mathrm{ppm}$ of vanadium there is a strong correlation between the changes of activities of kininase I, II, and of plasma renin. A partial relation exists on the other hand, between the activity of these enzymes and that of kallikrein and between urinary kallikrein activity and plasma aldosterone. It is not known whether these modifications are the result of a direct effect of vanadate or whether they are secondary, although it was shown that the activity of the kallikrein-kinin, reninangiotensin-aldosterone, prostaglandin, and enkephalinergic systems are correlated. ${ }^{23}$

In conclusion, this research shows that long term exposure to vanadate induces an increase of blood pressure in rats that is not dose-dependent. The role of defective renal function in such an effect was supported by alterations in the urinary excretion of electrolytes and in the activities of the kallikrein-kinin and renin-angiotensinaldosterone systems.

A part of this paper has been presented as an oral communication at the EUROTOX Congress, Maastricht, The Netherlands, 1-4 September 1991 and at the Congress trace 15-22 May 1993.
1 Nechay BR, Nanninga LB, Nechay PSE, et al. Role of vanadium in biology. Fed Proc 1986;45:123-32.

2 Nielsen FH, Urich $K$, Uthus EO. Interactions among vanadium, iron and cystine in rats. Growth, blood parameters and organ wt/body ratios. Biol Trace Elem Res 1984;6:117-32.

3 Sabbioni E, Pozzi G, Pintar A, Casella L, Garattini S Cellular retention, citotoxicity and morphological transCellular retention, citotoxicity and morphological transformation by vanadium(IV) and vanadium(V)

4 Sabbioni E, Clerici L. Brazzarelli A. Different effects of vanadium ions on some DNA-metabolizing enzymes. $f$ Toxicol Environ Health 1983;12:737-48.

5 Sabbioni E, Goetz L, Bignoli G. Health and environmental implications of trace metals released from coal fired plants: an assessment study of the situation in the European Community. Sci Total Environ 1984;40. 141-54.

6 Sabbioni E, Maroni M. A study on vanadium in workers from oil fired power plants. Luxemburg: CEC, 1984. Report EUR 9004.

7 Steffen RP, Pamnani MB, Clough DL, Huot SJ, Muldom SM, Haddy FJ. Effect of prolonged dietary administration of vanadate on blood pressure in the rat. Hypertension 1981;3:1173-8.

8 Carmignani M, Sabbioni E, Boscolo P, Pietra E, Ripanti G. Cardiovascular effects of long-term exposure to vana$G$. Cardiovascular effects of long-term exposure to vana-
date in rats. In: Anke $M$, Baumann $W$, et al, (eds). 6th date in rats. In: Anke M, Baumann W, et al, (eds). 6th International trace element symposium

9 Carmignani M, Boscolo P, Volpe AR, Togna G, Masciocco L, Preziosi G. Cardiovascular system and kidney as specific targets of chronic exposure to vanadate in the rat: functional and morphological findings. Arch Toxicol 1991;14(suppl):124-7.

10 Sundet WD, Wang BC, Hakumärri MOK, Goetz KL. Cardiovascular and renin responses to vanadate in the conscious dog. attenuation after calcium channel blockconscious d. Proc Soc Exp Bil Med 1984:175:185-90.

11 Crawford W, Teamy RJ, Hawthorne EW. Increased myocardial contractility during the initial period of myocardial contractility during the initial period of Fypertension in dogs following ren

12 Davidson DM, Cowell JW, Mallock CI, Ross J, Jr. Factors influencing indices of left ventricle contractility in the conscious dog. Cardiovasc Res 1974;8:299-312.

13 Freedlender AE, Goodfriend TL. Renin and the angiotensins. In: Jaffe BM, Behrman HR, eds. Methods of hormone radioimmunoassay. New York: Academi Press, 1979:889-913.

14 Abraham GE, Garza AR, Manlimos FS. Radioimmunoassay of steroids. In: Abraham GE, ed. 1977:591-618.

15 Pearse AGE. Histochemistry, theoretical and applied. Vol II Edinburgh: Churchill-Livingstone, 1972

16 Morita $T$, Kato $H$, Iwanaga $S$, Takada $K$, Kimura $T$, Sakakibara S. New fluorogenic substrates for $a$-trombin, factor $\mathrm{Xa}$, kallikreins and urokinase. $\mathcal{F}$ Biochem (Tokyo) factor Xa, kallik

17 Volpe AR, Porcelli G, Di Iorio M. Determination of kininase I and II activities in human urine by HPLC. $\mathcal{f}$ Chromatogr 1989;414:427-31.

18 Dunnet CW. New tables for multiple comparison with a control. Biometrics 1964;3:482-7.

19 Carmignani M, Volpe AR, Porcelli G, Boscolo P, Preziosi $P$. Chronic exposure to vanadate as factor of arterial hypertension in the rat: toxicodynamic mechanisms. In: EUROTOX Congress, Maastricht, September 1991. Medical Toxicology, Arch Toxicol Suppl 1992;15: 117-20.

20 Carmignani M, Volpe AR, Porcelli G, Boscolo P, Sabbioni E, Preziosi $P$. Vanadate exposure leads to arterial hypertension mainly through effects on peptidergic, catetension mainly through effects on peptidergic, cate1992; (suppl; abstracts of the sixth international con1992; (suppl; abstracts of the sixth international 21 Marmé D. Calcium and cell physiology. Berlin: Springer

22 Churchill PC, Rossi NF, Churchill MC, Ellis VR. Vanadate-induced inhibition of renin secretion is unrelated to inhibition Na,K-ATPase activity. Life Sci 1990; 46:1953-9.

23 Scicli AG, Carrettero AO, Renal kallikrein-kinin system. Kidney Int 1986;29:120-30. 